\title{
ISPANŲ KALBOS LIETUVIŠKOS KILMĖS DAIKTAVARDŽIŲ, RODANČIŲ GYVENAMĄJĄ VIETĄ, TYRIMAS IR NORMINIMAS
}

\author{
Aleksas Eugenijus Kulvietis \\ Lietuvos aukštoji jūreivystès mokykla
}

\begin{abstract}
Anotacija. Šiame tiriamajame darbe bandoma iš ispanu kalboje asmens kilmei nurodyti vartojamu žodžiu darybos formantu atrinkti ir pateikti tuos, kurie būtu priimtiniausi sudarant žodžius su lietuviškais miestu ir vietoviu pavadinimais. Globalejjančiame pasaulyje vykstant vis glaudesniems tarpkultūriniams kontaktams, kalbos vartotojai susiduria su klausimu, kaip pavadinti vieno ar kito miesto gyventojus. Šis klausimas su kiekviena diena tampa vis aktualesnis: jị vis dažniau kelia vertejai, žurnalistai, rašytojai - visi, kam svarbu perteikti savo patirtis, susijusias su mūsu kraštu, kultūra, teritorija, istorija.

Siekiant išsiaiškinti, kokios priesagos, kalbant apie lietuviškos kilmès gentilicijas, labiausiai bütu priimtinos ispanakalbiams vartotojams, buvo atliktas tyrimas, kurio metu, pasitelkus klausimyna, ispanakalbiu, pažistančiu Lietuva, gyvenusiu ar gyvenančiu joje, ir lietuviu ispanistu buvo prašoma atrinkti labiausiai jiems priimtinus kilmę rodančius žodžius, sudarytus iš svarbiausiu Lietuvos miestu pavadinimu. Apklausos rezultatai parodè, kad procentiškai ispanu pasirinkti formantai sutampa su dažniausiai vartojamais žodžiu darybai su ispaniškos kilmès pavadinimais pasirenkamais formantais ir kad, kaip ir ispany kalboje, neįmanoma nustatyti darybiniu formantu pasirinkimo sistemiškumo.
\end{abstract}

Reikšminiai žodžiai: lyginamoji lingvistika, ispanu kalba, norminimas, gentilicija, tautonimai, etnonimai.

\section{Ivadas}

Lietuvių kalboje priesagų, su kuriomis sudaromi būdvardžiai ir daiktavardžiai, nurodantys asmens kilmès vietą ar šalị, sistema gana nesudètinga, tačiau kartais ji vis dar kelia diskusijų. O štai ispanų kalboje, atvirkščiai, sistema iki šiol nėra nusistovejjusi, o dèl gausybės vartojamų šiam tikslui priesagų vis dar ginčijamasi, kaip elgtis su pavadinimais, kilusiais iš ispaniškų vietovardžių, jau nekalbant apie kilusius iš kitų kalbų.

Šiuo darbu siekiama parengti pasiūlymą Karališkajai ispanų kalbos akademijai ir Ispanų kalbos gelbejjimo fondui (Fundeu BBVA), kurie ieško galimybių ir sprendimų norminant ne ispanų (taigi, ir lietuviškos) kilmès tautovardžius ir daiktavardžius, rodančius asmens kilmès vietą (gentilicijas), ir palengvinti komunikaciją 
bei papildyti enciklopedinius šaltinius.

Tyrimo problema - globalejjančiame pasaulyje vykstant vis glaudesniems tarpkultūriniams kontaktams, kalbos vartotojai susiduria su vietovardžių pavadinimų problema.

Tyrimo tikslas - išsiaiškinti, kokios priesagos, kalbant apie lietuviškos kilmès gentilicijas, labiausiai būtų priimtinos ispanakalbiams.

Tyrimo objektas - priesagos, labiausiai priimtinos ispanakalbiams.

Tyrimo uždaviniai:

1. atlikti tyrimą ir rasti ispanišką gentiliciją, labiausiai tinkančią Lietuvos miestų gyventojams apibūdinti;

2. išsiaiškinti, ar respondentų atsakymai yra susiję su socialiniu vaidmeniu, kurị respondentai atlieka; tinkami.

3. patikrinti, ar egzistuoja galima sistema ir kokie darybiniai formantai yra

Tyrimo metodai: apklausa (elektroninè ir tiesioginè), anketa, mokslinès, metodinès literatūros, dokumentų analizè, statistinių duomenų lyginimas ir interpretavimas, sintezè.

Kai kalbame apie ispanų kalbos gentilicijas, kalbame apie fenomeną, kuris yra fiksuojamas visose moderniosiose kalbose ir, galima sakyti, visoms joms yra bendras - jis prisideda prie kalbų kitimo, evoliucionavimo ir variacijų. Ispanų kalboje turime begalę pasirinkimo galimybių - darybiniai formantai gali būti pasirenkami lanksčiai, o jų pasirinkimas greičiausiai tiesiogiai priklauso nuo socialinès terpès.

Pažiūrèkime, ką apie tai sako šiandienos autoritetai. Kalba yra kintanti. Pagal Coseriu kalbos kitimo koncepcijos teoriją, kalbantieji renkasi skirtingus kalbos elementus skirtingiems dalykams nusakyti, taip pat gali skirtingus elementus vartoti kalbẻdami apie tą patị dalyką. Sociolingvistiné ịvairové - tai dviejų ar daugiau elementų, o kartais ir to paties supriešinimas net tada, kai nèra jokios priešpriešos, arba semantinès prasmès pakeitimas suteikiant jai papildomą lingvistinị ir socialini atspalvị.

Grįžtant prie mūsų temos reikia pažymèti, kad pagrindiniai dalykai, kurie kalbą daro variantiška ir kintančia, yra galutinè kalbos siekiamybẻ būti informatyvia ir interpretatyvia. Iš tiesų, siekdama išlikti informatyvia, kalba perteikia jai nepriklausančią realybę. Bazinis lingvistinis veiksmas yra iš esmės interpretacinis, mat dèl savo interpretacinès siekiamybès kalba realybę perteikia kaip išjaustą žmogaus, arba kitaip - kaip žmogaus sąmonès turinị. Žodžiai, kaip sakè senieji graiku išminčiai, yra simboliai to, kas nutinka dvasioje.

Negalime būti absoliučiai tikri, kad tai, ką galvojame, vèliau sugebėsime išsakyti. Mes mąstome toje erdveje, kurią kalba sumodeliavo iš anksto. Tai, ką galime nusakyti, apibrèžia ir pertvarko tai, ką galime mąstyti. Žmogus jau gimsta kalboje ir kiekviena jo išmokta kalba jau yra iš anksto aktyvi, nes joje yra sukaupta kitu jos vartotoju patirtis. Interpretacinès ir informacinès veiklos rezultatai yra reikšmè ir 
ịvardijimas. Sociolingvistinis refleksyvumas yra tarsi konstruojantis mechanizmas, skatinamas ir valdomas lingvistinès komunikacijos, kuri pasireiškia kognityvinèmis kalbančiųjų lingvistinių ir sociokultūrinių resursų reprezentacijomis, norminimu, vertinimais ir aprašymais. Sociolingvistika tyrinejja kalbos vartojimo ir socialinio organizavimo struktūros efektą. Taip savo variacionistinès sociolingvistikos teorijoje teigia W. Labovas. Jis naudoja ịvairius statistinès koreliacinès analizès ir probabilistini metodus. Vienas reikšmingiausių šios disciplinos atstovų R. Wardhaughas sociumo kompleksiškumą ir naudingumą pasitelkia lingvistinėms studijoms. Tuo pat metu skirtingų kalbų egzistavimas toje pačioje socialinėje erdvejje gali pateikti įdomių lingvistinių pavyzdžių. Sociumas iš esmès gyvena skirtingose kalbose, tai yra multilingvistinè erdvè, kuri juda. Multilingvizmo erdvejje gali dominuoti kosmopolitinès dvikalbès, daugiakalbès erdvès, o kalbos čia gali patirti ypatingą izoliaciją ir tos erdvės viduje imti kurti savotiškus getus. Daugelis kitų aspektu, kuriuos nagrinejja sociolingvistika, mums padeda suprasti pokyčius ir kalbos elementų vartojimo pasirinkimus, kaip ir galimybę pasirinkti gentilicijų sudarymo variantą, kuris akivaizdžiai yra heterogeninis dèl neišmatuojamos ispanų kalbos paplitimo teritorijos. Nors priežasčių, kurių būtų galima ieškoti tradicijoje ar prestiže, o dar geriau - miestui būdingos kalbos inovacijoms, būtent tokioms, kurios, pasak Mac'o Gioll'os, yra lingvistinių pokyčių variklis (Giolla, 2007, 1).

Levas Vigockis, remdamasis Sociokultūrinès lingvistikos teorija, tikina, kad kalba yra mūsų aplinką reprezentuojantis komunikacinių funkcijų vienetas. Šis autorius pažymi, kad „,per intersocialinius ir lingvistinius veiksmus bendruomenès nariai, turintys daugiau metų ir patirties, moko jaunesniuosius ir dar nepatyrusius vertybių ir pažinimo mechanizmų, kad mokytiniai taptų produktyviais tos bendruomenès nariais“. Designacijos, arba ịvardijimo, procese, kur kalbos nešiotojas yra ekstralingvistinių elementų, kurie yra spontaniški ir susiję su giliaja ženklo kaip sintagmos monemos, suteiktos bendrosios reikšmès asignavimui, tokios kaip struktūra, aktorius (veikèjas), galime duoti L. Wittgenstein'o „gilumos“ terminą, vèliau vartotą ir plètotą Ch. Hockett'o ir galiausiai N. Chomsk'io perfrazuotą i ,giliają struktūrą" (Di Mauro, 1986, 82) ir kalbančiojo intuiciją komunikacijos momentu. Lygiai tas pats pasakytina apie gentilicijas.

Egzistuoja dar daugybė teorijų, kurios vienaip ar kitaip teigia kalbą varijuojant ir kintant, tačiau tik sociolingvistika nuo pat pradžių akcentuoja miesto kontekstą. Be abejo, čia prasideda ir nauja disciplina - ekolingvistika. Vienas jos pirmtakų - H. Haarmann'as. Jis miestą laiko urbanistine ekosistema. Jị domina individų ir bendruomenių, kalbančiu skirtingomis kalbomis, gebejimas sąveikauti miesto erdveje. Šios teorijos atstovai kalbą laiko ekosistema, o 8-ajame dešimtmetyje imama mąstyti, kad „lingvistinė ekologija turètų apimti visus socialinių ryšių tinklus, kurie kontroliuoja šnekos ir kalbančiųų sąveikas“" (Haarmann H., 1986, 3). 


\section{Kas yra „gentilicija“}

Kaip aiškinama DRAE (2014), žodis gentilicio kilo iš lotyniško termino gentilitǐus - daiktavardžio, kuris kartais kildinamas taip pat ir iš lotynų kalbos žodžio gens. Prisiminkime, kad senovès Romoje gens reiškẻ giminès liniją, klaną, šeimos grupę. Ši grupès, bendruomenès idèja išlaikoma, kai mes kreipiamès ị čiliečius, kolumbiečius, arekipiečių kaimiečius ar majus, taigi jis apima tiek tautovardžius, tiek šalėvardžius.

Gentilicio (šiame straipsnyje vartosiu terminą ,gentilicija“, nes jis apima tautonimus, etnonimus, vardus ir pavardes, daiktų kilmę nurodančius žodžius ir t. t.). Iš lot. gentilicius, išvest. iš gentīlis, - tas, kuris priklauso tai pačiai tautai ar giminès linijai: iš tam tikros vietos, šalies ,kilęs, susijęs ar priklauso $<\ldots>$ tam tikrai teritorijai, šaliai, tautai, regionui, zonai, miestui ir t. t.“ (Pérez M, 2012) Tai:

1. Daiktavardiškas būdvardis, rodantis sąsają su geografine vietove.

2. Būdvardis, rodantis priklausomybę genčiai ar tautai.

3. Būdvardis, rodantis priklausomybę giminès linijai arba šeimai.

\section{Aktualumas ispanų kalboje}

Neispaniškos kilmès daiktavardžių, rodančių kilmès vietą, ispanų kalboje kasdien vis daugèja. Jie masiškai fiksuojami komunikacijos priemonėse, spaudoje, formalioje ir neformalioje aplinkoje vartojamoje kalboje.

Kontaktai su kitomis kultūromis (kalbinėmis taip pat) stiprèja, veikia kalbą, verčia ją reaguoti, priimti informaciją, naujus žodžius ir apsispręsti, ką iš naujovių priimti, o ką atmesti. Karališkoji ispanų kalbos akademija (RAE), bandydama sunorminti tokius daiktavardžius, yra sudariusi ir patvirtinusi iš pasaulinès reikšmès miestų kilusias „,gentilicijas“, ir jos vartojamos komunikacijos priemonių. Nèra vienos bendros taisyklès „gentilicijai“ sudaryti. Dar daugiau, Naujojoje ispany kalbos gramatikoje (Gra matika, 2009, 7.6c) sakoma, kad „neįmanoma nustatyti, kokia tvarka turi būti parenkamas formantas šiems naujadarams iš kitų kalbų vietovardžių sudaryti“. Ten pat užduodamas klausimas: kaip tiksliau pasakyti - peruense, peruino ar perueño?

Rodos, neturètų būti sunku pasirinkti, tačiau dažnai nuomonès išsiskiria. Ir dažnai tos pačios vietovès gyventojui įvardyti vartojami keli skirtingi žodžiai. Lingvistinè sistema mums siūlo ne tik platų darybinių formantų pasirinkimą, bet kartu ir kitas funkcijas, tokias kaip kokybę ir sąsajas, papildančias įvardijamojo reikšmę. Tai gerai matyti 1 lenteleje.

Tokia tautovardžių ir kilmėvardžių ịvairovė rodo, jog ispanų kalba priima šią ịvairovę todèl, kad ji - neatsiejama kultūros, istorijos, tradicijos ir, galiausiai, gyvos kalbos dalis. Vienos formos vartojamos dažniau nei kitos, nes kiekvienas atvejis turi savo istoriją. Pasitaiko daiktavardžių, kilusių iš sutampančių pavadinimų vietovardžių, kuriais ịvardyti visiškai kitų geografinių regionų gyventojai, iš 
ten kilę, tokiu atveju dažniausiai pasirenkami skirtingi formantai: santiaguino (iš Santiago de Chile, Čilèje), santiaguense (iš Santiago de los Caballeros, Dominikos Respublikoje), santiagueño (iš Santiago del Estero, Argentinoje), santiaguero (iš Santiago de Cuba, Kuboje), santiagués (iš Santiago de Compostela, Ispanijoje).

Taigi, jie priklauso nuo regiono, o juos sudarant vadovaujamasi distingtyviniu principu arba nelingvistiniais principais bei atsižvelgiama i vietos gyventoju kalbinius ịpročius ir ị tai, kaip vadinami jie patys nori būti.

\section{Ispanų kalbos gentilicijų morfologija ir paplitimas}

Ispanų kalbos gentilicijos sudaromos iš daiktavardžių, įvardijančių regioną, šalį, miestą ar kitą geografinę vietovę (toponimų). Dažniausiai jos nurodo giminę ir skaičių. Pvz.: Italia: italiano (adj., sing., masc.), italiana (adj., sing., fem.), italianos (adj., pl., masc.), italianas (adj., pl., fem.).

Kitos priesagos nesuponuoja giminès ir nurodo tik skaičių. Pvz.: Canada: canadiense (adj., sing., masc /fem.), canadienses (adj., pl., masc /fem.). Kaip pastebėjote, naujai sudaryti žodžiai pagal darybą yra būdvardžiai, tačiau vėliau vyksta daiktavardejjimo procesas, ir jie gali funkcionuoti kaip savarankiški daiktavardžiai. Jie sudaromi su eksocentrinėmis tiek homogeninèmis, tiek heterogeninėmis priesagomis. Pvz.: Los lituanos (daiktavardis) son muy hospitalarios. Varios letones (daiktavardis) llegaron a la conferencia.

Gentilicija nurodo, iš kur kilusi kalba. Pvz.: la lengua alemana, el idioma alemán (būdvardis).

Arba yra savarankiškas daiktavardis. Pvz.: Hansel es un amigo frances $y$ habla alemán (būdvardis) + (daiktavardis). Jei nevartojamos gentilicijos, norint nurodyti kilmę, vartojama prielinksninè konstrukcija, pvz.: mujer de Vilnius, hombre de Kaunas.

Veikiant kalbos ekonomikos dèsniams tokia vartosena yra ne tokia dažna.

Tokiu būdu formuojami tikriniai vardai ir pavardès (andronimai), tačiau jie sudaro tik $2 \%$ ispaniškos kilmès andronimų, pvz.: De la torre, De los ríos, Del castillo ir pan. Toks kilmès nurodymo būdas būdingas ir kitoms kalboms.

Būdvardžių paradigmatika apima jų sudarymą iš dviejų pamatinių žodžių, kai vienas yra gentilicija, o kitas - etnonimas, taip pat ji gali būti sudaryta iš dviejų ar daugiau skirtingų gentilicijų. Keičiama tik paskutine šaknis, kitoms pridedama priesaga -o- , o žodžiai atskiriami brūkšneliu. Pvz.: Es un profesor colombolituano. Vadovaujantis bendraja taisykle, sintaksiškai ispanų kalboje būdvardis eina po daiktavardžio. Pvz.: Son naranjas españolas y bananos colombianos. Nustatyti, tai daiktavardis ar būdvardis, reikalingas kontekstas. 
1 lentelè. Ispanų kalbos gentilicijų formantai

\begin{tabular}{|l|l|l|l|}
\hline Vyrg. & Mot.g. & Pvz. & Liet. \\
\hline -o & -a & ruso & rusas \\
\hline -ano & -ana & lituano & lietuvis \\
\hline -eno & -ena & chileno & čilietis \\
\hline -etano & -etana & turdetano & turdetanas \\
\hline -eño & -eña & panameño & panamietis \\
\hline -ino & -ina & latino & lotynas \\
\hline -aino & -aina & vizcaino & biskajietis \\
\hline -aro & -ara & húngaro & vengras \\
\hline -aco & -aca & polaco & lenkas \\
\hline -eco & -eca & sueco & švedas \\
\hline -esco & -esca & portugués & portugalas \\
\hline -isco & -isca & morisco & marokietis \\
\hline
\end{tabular}

\begin{tabular}{|l|l|l|l|}
\hline Vyr.g. & Mot.g. & Pvz. & Liet. \\
\hline -i & - i & iraní & iranietis \\
\hline -a & -a & belga & belgas \\
\hline -ata & -ata & croata & kroatas \\
\hline -ota & -ota & chipriota & kiprietis \\
\hline -ita & -ita & chiita & šiitas \\
\hline -ense & -ense & canadiense & kanadietis \\
\hline -án & -ana & alemán & vokietis \\
\hline -ol & -ola & español & ispanas \\
\hline -és & -esa & japonés & japonas \\
\hline -uz & -uza & andaluz & andalūzas \\
\hline -iego & -iega & griego & graikas \\
\hline -ego & -ega & gallego & galas \\
\hline
\end{tabular}

\section{Asmenų pavadinimai pagal jų kilmès ir gyvenamąją vietą lietuvių kalboje}

Lietuvių kalboje ši sistema iš pirmo žvilgsnio kur kas paprastesnè. Priesagų vediniai yra keturi (DLKG, 1994, 139-40):

1. - ietis $(-\dot{e})$ - labiausiai ịprasta ir dažniausiai vartojama šios grupès priesaga. $\mathrm{Su}$ ja sudaromi asmenų pavadinimai iš jų gyvenamujų ar gyventojų miestų, žemynų ir valstybių tikrinių, taip pat bendrinių vietos pavadinimų, vediniai arba naujadarai, kurie žymi asmenų priklausymą ideologijai, jų veiklą ir t. t.;

2. su priesaga -iškis $(-\dot{e})$, kaip ir su -ietis $(-\dot{e})$, labiausiai ịprasta daryti asmenu pavadinimus iš gyvenamųjų ar gyventojų miestų ar miestelių pavadinimų. Bendrinèje kalboje juos vis labiau išstumia priesaga -ietis $(-\dot{e})$, bet tarmèse vis dar labiau ir plačiau vartojama priesaga $-i s ̌ k i s ~(-\dot{e})$.

3. - enas $(-\dot{e})$ - su šia priesaga tikrinių vardų pavadinimų ne taip dažna (daugiau vartoja rytų aukštaičiai);

4. -inis $(-\dot{e})$ priesaga vartojama kai kuriose lietuvių kalbos rytų šnektose, pvz.: galinis, miškinis, paringinis.

Galūnių vediniai -is, -ius. Bendrinèje kalboje nèra ịprasta daryti asmenu pavadinimų iš gyvenamųų ar gyventojų miestų, miestelių pavadinimų. Tarmése esama tokių vedinių: lietuvis, linkuvis, kalnius. Naujai padaryti žodžiai norminami vadovaujantis keturiais principais:

- tradicija - jei žodis fiksuotas žodynuose;

- analogija - jei minètuose šaltiniuose pavadinimo nėra, jis padaromas pagal analogiją su kitais panašiais kalboje jau įsitvirtinusiais žodžiais;

- distinktyvumas - jei valstybės pavadinimas yra keliažodis ir darant viena- 
žodị gyventojo pavadinimą gali kilti kokių nors dviprasmybių, geriau tos valstybės gyventojus vadinti sudètiniu pavadinimu;

- sistemiškumas - jei nèra nei tradicijos, nei analogijos, bet leidžia darybos taisyklès. Be to, taip lengviausiai tokio tipo žodžius pasidaro ir paprasti kalbos vartotojai.

Kaip jau minèta, lietuvių kalboje yra keturios gentilicijų darybos priesagos. $\mathrm{Su}$ jomis padaryti būdvardžiai yra sudaiktavardèję. Nors tokios priesagos yra tik keturios, lietuviams vis dar neaišku, kada kurią vartoti (Liutkevičienè, 2003, 80-84).

Pirmiausia reikia pasakyti, kad valstybių gyventojų pavadinimai ir tautovardžiai lietuvių kalboje ne visada sutampa. Antai Airijoje gyvena airių, Rusijoje - rusų tauta, tačiau belgais vadinami Belgijoje gyvenantys flamandų, valonų ar vokiečių tautybès žmonès. Žodis angoliečiai reiškia Angolos gyventojus, o ne tautybę, mat Angoloje yra daug tautų ir etninių grupių.

Priesagos -iškas $(-a)$ vediniai reiškia:

1) ypatybę pagal panašumą, pvz., ãsiliškas, bróliškas, dangiška;

2) ypatybę pagal daikto priklausymą rūšiai, pvz., kareiviški batai, lénkiški obuoliai;

3) perkeltine reikšme vartojami dariniai, pvz., milžiniškas darbas.

Šios priesagos darumą rodo daugybė vedinių iš tarptautinių žodžių: apãtiškas, ekonòmiškas, elegantiškas, mãgiškas, lògiškas ir kt.

Šis formantas atitinka ispanų gentilicijas - būdvardžius ir greičiausiai yra senuosius raštus paveikusios lotynų kalbos palikimas.

\section{Tyrimas}

Kad galètume ištirti iškeltą problema, atsižvelgdami ị tai, kad ši tema kol kas visiškai nèra tyrinèta, nusprendème empiriniu būdu atlikti tyrimą ir rasti ispanišką gentiliciją, labiausiai tinkančią Lietuvos miestų gyventojams apibūdinti. Kaip teorinejje dalyje pažymėta, miestai yra tai, ị ką mes ir sutelksime dėmesị ir bandysime pažvelgti i juos sociolingvistiškai, būtent čia galèsime patvirtinti arba paneigti suformuluotas teorijas. Mūsų tyrimas taip pat buvo atliekamas norint išsiaiškinti, ar respondentų atsakymai yra susiję su socialiniu vaidmeniu, kurị respondentai atlie$\mathrm{ka}$, ir patikrinti, ar egzistuoja galima sistema, kuria vadovaudamiesi jie pasirenka, kokius darybinius formantus laikys tinkamais.

Tyrimo objektas - 54 Lietuvos miestų pavadinimai.

Duomenų rinkimo būdai: elektroninè ir tiesioginè apklausa.

Tyrimo dalyviai - 50 asmenų. Tikslinè grupè: pilnamečiai vyrai ir moterys, ispanakalbiai, turintys ryšių su Lietuva arba gyvenantys joje. 
1 grafikas. Gentilicijų darybinių priesagų

pasiskirstymas ispanų kalboje

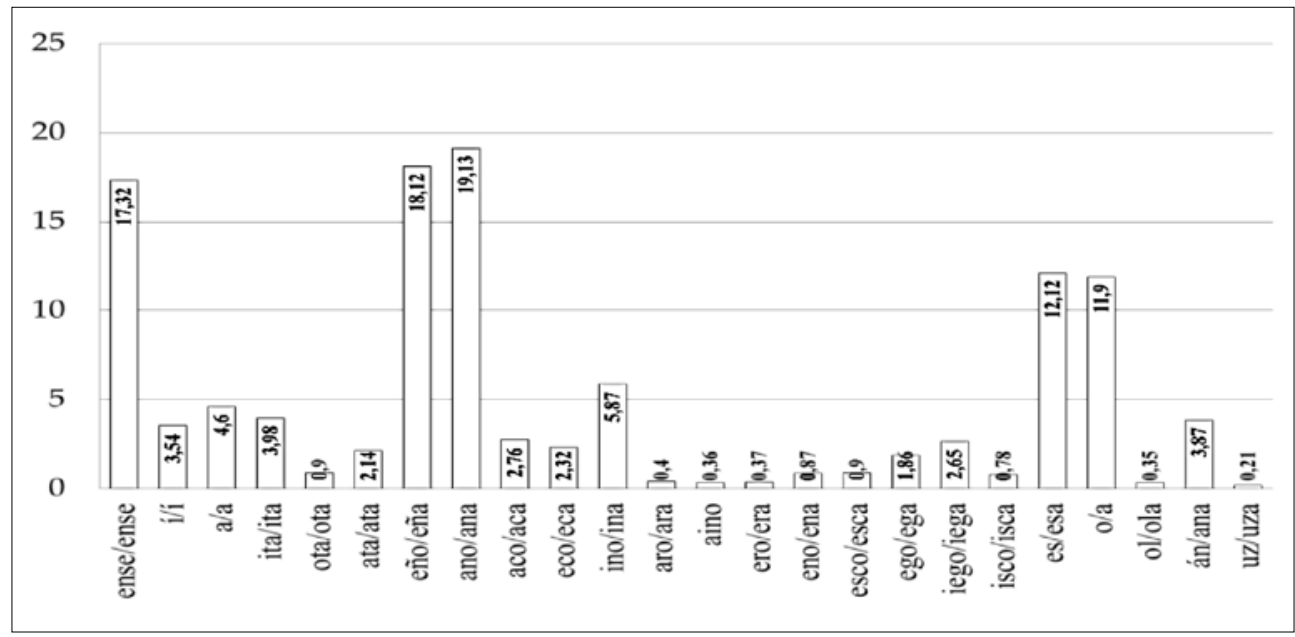

Pirmiausia buvo atlikta statistinè analizè, kokius formantus gentilicijų darybai statistiškai dažniausiai vartoja ispanai. Tam buvo pasitelktas ispanų kalbos žodynas, o gautas rezultatas atsispindi 1-ame grafike. Pažymètina, kad dažniausiai gentilicijoms sudaryti vartojamos 4 priesagos: -ense/-ense (17,32 \% gentilicijų, užfiksuotų Virtualiame gentilicijų žodyne $)$, -eño/-eña $(18,12 \%)$, ano/-ana $(19,13 \%)$ ir -eso/-esa $(12,12 \%)$.

Apklausos forma: kiekvieno dalyvio buvo paprašyta užpildyti lentelę sudarant gentiliciją, kuria, jų nuomone, labiausiai tiktų pavadinti nurodytų Lietuvos miestų gyventojus.

Apibendrinamosioms išvadoms padaryti buvo paimti dažniausiai pasitaikę kiekvieno miesto gyventojų pavadinimai.

Reikia pažymèti, kad, siekiant išvengti nesusipratimų, šis tyrimas turètų būti tęsiamas apklausiant ir lietuvius, mokančius ispanų kalbą (vertejus, dėstytojus arba turinčius $\mathrm{C} 1$ ispanų kalbos mokejjimo ịvertinimą).

Taip pat pažymètina, kad šis tyrimas vis dar yra preliminarus, nes hipotetiškai dirbti su tokiu plačiu pavyzdžių lauku (respondentai yra ispanakalbiai, gyvenantys skirtingose šalyse, dẻl to jų darybinių formantų pasirinkimą gali lemti skirtingos ispanų kalbos teritorinès savybès) $)^{2}$, o tai gali tiesiogiai paveikti tyrimo rezultatus.

1 Diccionario virtual de gentilicios (Virtualus gentilicijų žodynas), http://gentilicios.gratis.es/ gentilicio-z/.

2 Labai skirtingus formantus renkasi Pietų Amerikos ir Pietų Ispanijos ispanų kalba kalbantieji respondentai. 


\section{Tyrimo eiga}

Pirmiausia buvo atlikta toponimų transliteracija (kol kas oficialiai nepatvirtinta). Siekta, kad Lietuvos miestų pavadinimai būtų užrašyti taip, kad ispanakalbiai juos ištartų kuo panašiau į lietuvių kalbą. Šiam tikslui pasiekti buvo vadovaujamasi Karališkosios ispanų kalbos akademijos rekomendacijomis ${ }^{3}$.

\section{Analizė ir rezultatai}

Susumavus rezultatus galima pastebèti, kad ispanakalbių pritaikytos leksinès struktūros Lietuvos miestų gyventojams pavadinti beveik atitinka bendrą ispaniškujų gentilicijų tendenciją ir kad situacija nèra tokia chaotiška, kaip gali pasirodyti iš pirmo žvilgsnio.

Tai akivaizdu pažvelgus ị 2 lentelę. Ja remiantis galima teigti, kad ispanų kalboje išsiskiria keturios priesagos, su kuriomis dažniausiai sudaromos gentilicijos iš neispaniškų žodžių: -ense, -ano, -eño ir -se. Tos pačios priesagos dažniausiai buvo pasirinktos sudarant žodžius ir su lietuviškais toponimais.

Kiekvieno norminio pavartojimo atvejai sudaro $85 \%$. Tai rodo, kad žmonès vadovaujasi natūralia designatyvine tradicija, kuri leidžia visumai pritaikyti giluminę struktūrą kilmès vietai nusakyti.

1 lentelè. Apklausos rezultatai: pagrindinių Lietuvos miestų gyventojų pavadinimai ispaniškai

\begin{tabular}{|l|l|}
\hline akmeno & $36 \%$ \\
\hline alytano & $91 \%$ \\
\hline anikshio & $36 \%$ \\
\hline birshtonés & $29 \%$ \\
\hline birzhai & $25 \%$ \\
\hline druskininkés & $27 \%$ \\
\hline elektreno & $30 \%$ \\
\hline ignalino & $43 \%$ \\
\hline yonavés & $19 \%$ \\
\hline yonishkeli & $35 \%$ \\
\hline yonishki & $22 \%$ \\
\hline yurbarkano & $23 \%$ \\
\hline kaishiadorense & $34 \%$ \\
\hline kalvarihano/kalvariho & $25 \%$ \\
\hline kaunense & $45 \%$ \\
\hline kaslurudense & $20 \%$ \\
\hline kedeainense & $25 \%$ \\
\hline kelmeño & $22 \%$ \\
\hline klaipediense & $52 \%$ \\
\hline
\end{tabular}

\begin{tabular}{|l|l|}
\hline kretinguense, kretingueño & $32 \%$ \\
\hline kupishkeño & $23 \%$ \\
\hline lasdino & $32 \%$ \\
\hline marianpolés, mariampoleño & $21 \%$ \\
\hline mazheiki, mazheikino & $24 \%$ \\
\hline moletano & $45 \%$ \\
\hline neringués & $29 \%$ \\
\hline $\begin{array}{l}\text { pakrohiense, pakrohiano, } \\
\text { pakrohiego }\end{array}$ \\
$\begin{array}{l}\text { palangueño } \\
\text { panevezhense, panevezhino }\end{array}$ & $21 \%$ \\
\hline $\begin{array}{l}\text { pasvali } \\
\text { plunguense } \\
\text { prieno } \\
\text { radvilishkino, radviliskiso }\end{array}$ & $25 \%$ \\
\hline raseino & $27 \%$ \\
\hline rietavo & $23 \%$ \\
\hline rokishkes & $50 \%$ \\
\hline eskuodo & $28 \%$ \\
\hline
\end{tabular}

\begin{tabular}{|l|l|}
\hline shakiano & $45 \%$ \\
\hline shalchininko & $45 \%$ \\
\hline shaulense, shaulés & $27 \%$ \\
\hline shilales & $34 \%$ \\
\hline shiluteño & $31 \%$ \\
\hline shirvinto & $30 \%$ \\
\hline shvenshonisco & $26 \%$ \\
\hline tauraguense, tauragués & $35 \%$ \\
\hline telshiano & $55 \%$ \\
\hline trakano. trakraino & $25 \%$ \\
\hline ukmergués & $45 \%$ \\
\hline utenense & $49 \%$ \\
\hline vareno & $30 \%$ \\
\hline vilkavishko & $33 \%$ \\
\hline vilnense, vilniano & $32 \%$ \\
\hline visagino & $35 \%$ \\
\hline saraseño & $31 \%$ \\
\hline
\end{tabular}

3 Toponimai buvo adaptuojami laikantis tam tikrų kriterijų: transkripcijos, rašybos ir adaptacijos (arba dalinės adaptacijos); ispanų kalbos gramatikos taisyklių ir normų (hispanización); naudojant adaptuotus arba pusiau adaptuotus, tačiau respondentams aiškius rašmenis; pateikiant oficialiai galimus pakeitimus, neatmetant jau egzistuojančių galiojančių formų. Laikomasi šešių toponimų grupių, http://www.rae.es/diccionario-panhispanico-de-dudas. 
Daugelis apklaustujų pasirinko priesaga jungti prie toponimo šaknies, o ne prie galūnès. Tai ypač pasakytina apie lietuviškus toponimus su galūne (-i)ai. Galūninė daryba su $-i$ daugelio respondentų buvo skirta Joniškio gyventojų pavadinimams sudaryti: Yonishkí, daugiskaita - Yonishkies arba Yonishkís. Nemažai naujų daiktavardžių buvo sudaryti procentiškai tiek pat vartojant kelias priesagas: pakrohiense, pakrohiano, pakrohiego. Iš daiktavardžių, kurių gale buvo -is, -as, respondentų naujadarai buvo sudaryti prijungiant darybinị formantą prie galūnès: Rokish$k i s=$ Rokishkiso (iš Rokiškio). Tai pastebèta ir toponimo Šiauliai vartojimo atveju. Respondentai šalia tradicinio lotynų kalbos formanto -ense rinkosi ir priesagą -es nurodydami daugiskaitą (pasirinkta po $27 \%$ ).

Atsižvelgiant ị tai, kad ispanų kalba neturi frikatyvinès alveopalatalinès $/ \int /$, šis garsas ortografiškai žymimas sh. Akivaizdu, kad mes, ispanai, ši garsą skiriame ir vartojame onomatopejjiškai, tačiau mūsų ortografija neturi gramatikoje ịtvirtinto grafinio ženklo šiam garsui žymèti. Taigi, kaip matome 2 lenteleje, ispanakalbiai ji keičia pučiamuoju alveoliniu /s/ ir vartoja istorini lotyniškaji variantą -ense. Gali būti, kad sekant lotyniškaja rašytine tradicija ${ }^{4}$ vadinami bent jau didžiųų Lietuvos miestų gyventojai: saulensis (saulense), vilnensis (vilniense - net $32 \%$,) klaipedensis (klaipediense - $52 \%$ ), kaunensis (kaunense - $45 \%$ ). Galime palyginti 2 lentelę. Ši situacija labai panaši ị tą, kuri susiklostė sudarant ispaniškas gentilicijas iš kitų kalbų toponimų 5 .

2 lentelè. Formantų vartojimo sudarant gentilicijas iš ispaniškų ir lietuviškų toponimų lyginamoji lentelè

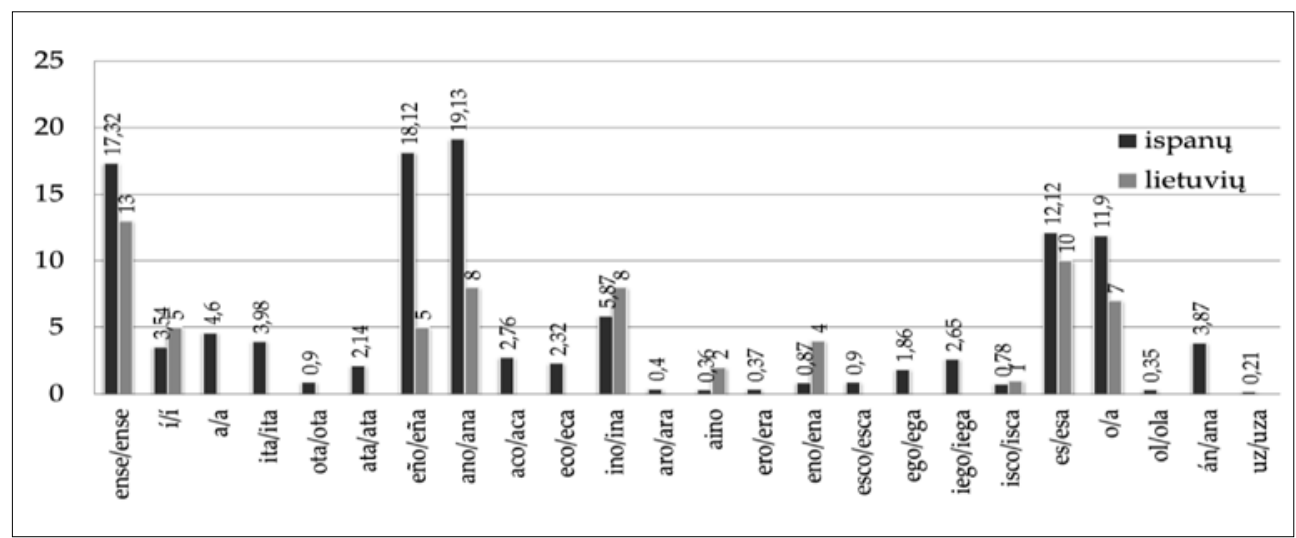

4 Beje, prie šios versijos paplitimo istoriškai prisideda ir lietuviai, laikydamiesi senosios raštijos pavyzdžių.

5 „Gentilicijos seulés ir seulense paprastai vartojamos asmenims, kilusiems iš Seulo, Pietų Korejos sostinès, ịvardinti, o štai ispanų kalbai priimtinas ir galimas variantas seulita labiau priskirtinas prancūzų kalbai“, - rašoma FUNDEU internetiniame ispanų norminès kalbos konsultacijų ir rekomendacijų portale (prieiga internetu: http://www.fundeu.es/ recomendacion/seulenseseules, žiūrèta [2016-02-21]). Šis atvejis labai panašus ị mūsų minètą su liet. toponimu Šiauliai. 
Lenteleje matome, kad, tiek sudarant gentilicijas su ispaniškais (tamsesni stulpeliai), tiek su lietuviškais (šviesesni stulpeliai) pavadinimais, dominuoja tie patys darybos formantai.

\section{Išvados}

Respondentų pritaikytos leksinès struktūros Lietuvos miestų gyventojams pavadinti beveik atitinka bendrą ispaniškuju gentilicijų darybos tendenciją.

Dažniausiai, kaip ir ispanų kalboje, sudarant gentilicijas su lietuviškais toponimais vartojamos keturios priesagos: -ense, -ano, -eño ir -se.

Lygiai kaip ir lietuvių kalboje, ispanų kalboje nèra labai aiškios sistemos, kaip turètų būti sudaromos anksčiau rašytiniuose šaltiniuose nepasitaikiusios getilicijos su lietuviškais toponimais. Dauguma kalbètojų turi natūralų (intuityvų) pojūtị, kokius darybos formantus pasirinkti, kad naujas žodis būtų maksimaliai aiškus ir informatyvus.

Kalbos institucijos turi palengvinti vartojimą, teikti su tuo susijusius pasiūlymus, atsižvelgdamos $\mathfrak{i}$ vyraujančias tendencijas ir kalbos principus.

Kartais dèl vienos skirtingos sistemos patekimo ị kitą gali kilti daug nesusipratimų, tačiau, radus sprendimo būdą, kaip parodè tyrimas, rezultatai gali būti naudingi ir padèti išvengti nesusikalbejjimo ir neaiškumų.

Ispanų kalbai galime taikyti tuos pačius lietuvių nustatytus principus, pagal kuriuos teikiami (norminami) vienokie ar kitokie valstybių gyventojų pavadinimai ir tautovardžiai.

Pasiūlymas, kaip ispaniškai vadinti Lietuvos miestų gyventojus, perduotas Karališkajai ispanų kalbos akademijai (Real Academia de la lengua española).

\section{Literatūra}

Pérez A. (2013). Los sufijos gentilicios: un grupo tan indiscutible como erróneo" Revista Cálamofaspe, 2013, nº 61, Madrid: Diálogos de la lengua, 12-21.

Ambrazas V. (2005). Dabartinès lietuvių kalbos gramatika. Vilnius: Mokslo ir enciklopedijų leidykla.

Coseriu E. (1977). Principios de semántica estructural. Madrid: Gredos.

Di Mauro T. (1986). „Minisemántica“, Madrid, Gredos, 82.

Haarmann H. (1986). Language in Ethnicity. A View of Basic Ecological Relations. Berlin: Mouton de Gruyter.

Labov W. (1983). Modelos sociolingüísticos. Madrid: Cátedra.

Liutkevičienė D. (2003). Valstybių gyventojų pavadinimai ir tautovardžiai. Lietuvių kalbos institutas. Vilnius: Kalbos kultūra 81, 80-84.

Giolla M. (2007). Language and the city. New York: Mcmillan.

Morera Perez M. (2012). El concepto de gentilicio: Estudios de morfología y léxico. San Millán de la Cogolla, Cilengua, 51-62. 
Pérez Vigaray J. (2012). El artículo lexicográfico de los sufijos con acepción gentilicia en español: su tratamiento en el DRAE-01, Valencia: XLI Simposio de la Sociedad Española de lingüística: 31.

R e a 1 A c a d e m i a E s p a ñ o 1 a (2010). Lista de países y capitales, con sus gentilicios, Ortografía de la lengua española, Madrid, Espasa, 722.

R e a 1 A c a d e m i a E s p a ñ o 1 a (2009). Nueva gramática de la lengua española. Madrid, Espasa, 241.

Lev V. (1964). Pensamiento y lenguaje. Buenos Aires: Editorial Lautaro.

Wardhaugh R. (1998). Introduccion a soclolinguistica Oxford: Blackwell. 76-47.

F u n d e u B B V A (2014). Directrices para la transcripción de palabras escritas en lenguas que usan escrituras no latinas: nombres propios, nombres comunes, criterios ortográficos [elektroninè versija].

F u n d a c i ó n E s p a ñ o 1 U r g e n t e 2006, Topónimos y gentilicios de las antiguas repúblicas socialistas.

Soviéticas [prieiga internete: http://web.archive.org/web/20070613215616/ http://www. fundeu.es/IMAGENES /revistaPDF/632956650695468750.pdf, 15].

M u ñ o z C, Muñoz D (2014). La ciudad en el lenguaje y el lenguaje en la ciudad. Madrid: Universidad Complutense de Madrid [prieiga internete: file://C:/ Users/EG/Downloads /DialnetLaCiuda dEnElLenguajeYElLenguajeDeLa Ciudad3262719.pdf> žiūrèta 2016-02-20].

Real Academia Española (2014). Adjetivo gentilicio, Diccionario de la lengua española (23. ${ }^{a}$ edición), Madrid: Espasa [prieiga internete: $<$ http://dle.rae.es /?id=J6BWnNL $>$, žiūrèta 2016-02-23].

Real Academia Española (2005). Diccionario panhispánico de dudas [prieiga internete: <http://www.rae.es/diccionario-panhispanico-de-dudas/apendices/ paises-y-capitales-con-sus-gentilicios|url>, žiūrèta 2016-02-23]. 


\title{
THE STUDY AND STANDARDISATION OF SPANISH NOUNS OF LITHUANIAN ORIGIN INDICATING PLACE OF RESIDENCE
}

\author{
Aleksas Eugenijus Kulvietis
}

Lithuanian Maritime Academy

\begin{abstract}
Summary
This research paper attempts to select the formants of complex formation of words used in the Spanish language to indicate the origin of a person and indicate those that are most acceptable to create words with names of Lithuanian towns and places. In the globalised world with intensifying intercultural contacts, the users face the issue of how to name the residents of certain cities or towns. The importance of this issue increases with each passing day and turns into a necessity as this issue is discussed with increasing frequency by translators, journalists, writers and all other people who find it important to convey their experience related to our country, culture, territory, and history. In order to find out what suffixes would be most acceptable in terms of gentilics of Lithuanian origin to Spanishspeaking users, a study was conducted using a questionnaire. The Spanish-speaking people, who know Lithuania, who have lived or lives here, and Lithuanian Hispanists were asked to select the origin-indicating words formed with the most important names of Lithuanian towns that they find most acceptable. The questionnaire results showed that the percentage of the formants selected by Spanish people coincide with the percentage of the most frequently used formants of Spanish-origin words and that, same as in the Spanish language, it is impossible to determine a systematic approach to selection of suffixes.
\end{abstract}

Keywords: comparative linguistics, spanish language, standardization, gentilic, tautonyms, ethnonyms 


\section{AUTORIAUS LYDRAŠTIS}

Autoriaus vardas, pavardė: Aleksas Eugenijus Kulvietis

Mokslo laipsnis ir vardas: ispanų kalbos specialistas, lektorius

Darbo vieta ir pareigos: Lietuvos aukštoji jūreivystès mokykla, I. Kanto g. 7, Klaipèda LT-92123

Autoriaus mokslinių interesų sritys: kalba ir kultūra

Telefonas ir el. pašto adresas: +370 614 87622, a.kulvietis@lajm.lt, aekulvietis@gmail.com

\section{AUTHOR'S COVER LETTER}

Author name, surname: Aleksas Eugenijus Kulvietis

Science degree and name: Spanish language specialist, lecturer

Workplace and position: Lithuanian Maritime Academy

Author's research interests: language and culture.

Telephone and e-mail address: +370 614 87622, a.kulvietis@lajm.lt, aekulvietis@gmail.com 